\title{
Pharmacognostic, Physicochemical Standardization and Phytochemical Analysis of leaves of Cultivated Crotalaria ladhnosema Stapf.
}

\author{
Jemilat A. Ibrahim ${ }^{1 *}$, Opeoluwa Makinde ${ }^{1}$ and Nneka N. Ibekwe ${ }^{2}$ \\ ${ }^{1}$ Department of Medicinal Plant Research and Traditional Medicine, National Institute for Pharmaceutical Research and Development (NIPRD), PMB 21, \\ Garki, Abuja. \\ ${ }^{2}$ Department of Medicinal Chemistry and Quality Control, National Institute for Pharmaceutical Research and Development (NIPRD), PMB 21, Garki, \\ Abuja.
}

\section{ARTICLE INFO}

Article history:

Received on: $22 / 08 / 2012$

Revised on: 08/09/2012

Accepted on: 15/09/2012

Available online: 28/09/2012

Key words:

Authentication,

chromatograph,

Macroscopic, Microscopic

\begin{abstract}
Towards authentication and quality assurance of medicinal plants, pharmacognostic, physicochemical and preliminary phytochemical studies of the leaves of Crotolaria lachnosema Stapf. were carried out. The macroscopic and microscopic evaluation revealed characters that are of diagnostic value and useful in authentication of the plant. The Physicochemical analyses reveals values for moisture content, alcohol extractive, water extractive and total ash which are within the World Health Organisation (WHO) standards for crude drug from medicinal plants. Phyto-screening for secondary metabolites revealed the presence of saponins, terpenes/steroids, flavonoids, resins and balsams, while alkaloids, glycosides and tannins were absent. Information obtained from these studies can be used as markers in the identification and standardization of this plant as a herbal remedy and also towards monograph development on the plant.
\end{abstract}

\section{INTRODUCTION}

The plant Crotalaria lachnosema Stapf. belongs to the family Fabaceae (Leguminosae), subfamily Papilionoideae. It is a woody plant with a height of about $2 \mathrm{~m}$ high. It is found along forest margin in damp sites (Burkill, 1995). The plant is known as 'Fara bi - rana' in Hausa, 'Kompo' in Yoruba, 'Ake dinwo' in Igbo and 'Birijibei' in Fulani (Nuhu et al, 2009). In a study carried out on the traditional medicinal uses of Crotalaria species, Crotalaria lachnosema was found to be important in the treatment of scabies. It was also found to be highly sorted after in love matters and acceptance (Nuhu et al., 2009). In the same study, it is said that the whole plant grounded and mix with water

* Corresponding Author

Dept of Medicinal Plant Research and Traditional Medicine, National Institute for Pharmaceutical Research and Development PMB 21, Garki, Abuja, Nigeria. Tel: 2348058293853 fed to animals to treat liver diseases (Nuhu et al., 2009). Pyrrolizidine alkaloids, a poisonous compound has been found to be present in Crotalaria spp and according to WHO report, many species of the genus have been reported to be toxic with epidemic outbreaks in some part of the world (WHO, 1988; Arzt and Mount, 1999). Bras et al. (1961) stated that only few species of the genus Crotalaria have been studied and also that WHO have labelled the Pyrrolozidine alkaloids as a very important toxicant and have made a call that all species of plants that might contain the alkaloid should be studied ethnomedicinally, phytochemically and taxonomically, etc (WHO,1988). Despite the medicinal importance of this species and its likely danger because of the presence of the Pyrrolizidine alkaloids, information on the pharmacognostic parameters for identification of this species in whole and powdered form are unavailable. The present study aimed at investigating the 
macromorphology, pharmacognostic evaluation and phytochemical screening of the leaves of Crotalaria lachnosema towards standardization and monograph development.

\section{MATERIALS AND METHODS}

\section{Sample collection and processing}

The plant was collected from Jos in Plateau state of Nigeria in the year 2009 and the seeds were planted in the botanical garden of National Institute for Pharmaceutical Research and Development (NIPRD) Idu, Abuja. The plant material used for this study was collected in the year 2010 from the botanical garden of the Institute. The plant was air dried indoor and powdered using mortar and pestle. The powdered sample was stored in air tight container for the phytochemical analysis.

\section{Pharmacognostic analysis Macromorphology}

Macromorphological characters of the leaves like leaf shape, size, colour, texture, margin type, apex, base and petiole size, flower colour and length etc were observed. Measurements were carried out using line ruler.

\section{Microscopic analysis}

Microscopic analysis was carried out on epidermal layers and transverse sections of leaf.

\section{Epidermal layers of leaves}

Leaves of the specimens were cut at the median portions. These were soaked in concentrated Nitric acid for about $24 \mathrm{hrs}$. The appearance of air bubbles indicated the readiness of the epidermises to be separated. The samples were then transferred to Petri dishes containing water and with the use of fine forceps and dissecting needle; the upper and lower epidermises were separated. One set was stained with saffranin and another one with Sudan IV and later mounted on a slide with glycerol. The edges of the cover slip were sealed with nail vanish to prevent dehydration.

\section{Transverse section of leaves}

Sections were manually obtained by sectioning with razor blade. The sections were cleared for some minutes in sodium hypochlorite solution. It was washed in water and then stained with Sudan IV. These were mounted on a slide with glycerol and edges were ringed with nail vanish to prevent dehydration. All slides were observed under a light microscope and photomicrograph taken using Leica CM E microscope with Digital Microscope Eyepiece attachment and Photo Explorer 8.0 SE Basic software.

\section{Physicochemical Analysis}

Physicochemical analyses were carried out on the powdered sample following standard methods (Sofowora, 2008; Evans, 2002; African Pharmacopeia, 1986). Moisture content, alcohol extractive value, water extractive value and total ash value were tested for.

\section{Phytochemical screening}

Preliminary phytochemical investigations for secondary metabolites were carried out on the powdered sample of the leaves of C. lachnosema using standard procedures (Sofowora, 2008; Evans, 2002). The metabolites tested for were carbohydrates, balsams, resins, saponins, sterols, terpenes, tannins, flavonoids, cardiac glycosides, glycosides, alkaloids and phlobatannins.

\section{Thin layer chromatography}

Thin-layer chromatography (TLC) was employed in the qualitative analysis of organic extracts of the powdered leaves. The plant material was extracted successively with hexane (Hex), ethyl acetate (EtOAc) and methanol (Meth) between intervals of 24 hours. The extracts were spotted on activated silica gel plates. Two solvent systems of Hex-EtOAc (9-1) and Hex-EtOAc-Meth (7-2-1) were used for development of the plates. Spots were detected on TLC plates by spraying with sulphuric acid, followed by charring at $110{ }^{\circ} \mathrm{C}$ for 10 minutes in an oven. The retention factor $(R \mathrm{f})$ for each spot was calculated using the formula:

$$
R \mathrm{f}=\frac{\text { Distance moved by solute }}{\text { Distance moved by solvent }}
$$

\section{RESULTS}

\section{Pharmacognostic analysis}

Macroscopical evaluation

C. lachenosema is a shrub, whole plant hairy. Stem densely brownish hairy and round in shape. Leaves thick and densely hairy on both surfaces, greenish in colour. Leaf venation more prominent on lower surface with submarginal nerves. Leaf is compound and alternate in arrangement with stipules. Petiole about $0.6-1 \mathrm{~cm}$ long. Leaflets are trifoliate and oblanceolate to oblong in shape, $3.7-6.7 \mathrm{~cm}$ x $1.5-2.5 \mathrm{~cm}$. Petiolule about $0.3 \mathrm{~cm}$ long. Middle leaflet is largest. Leaf apex slightly mucronate, base cuneate with entire margine. Flowers orange in colour. Fruit a legume, densely hairy, brownish in colour, about $1.5 \mathrm{~cm}$ to $2.5 \mathrm{~cm}$ long, almost oblong in shape (Figure 1).
A

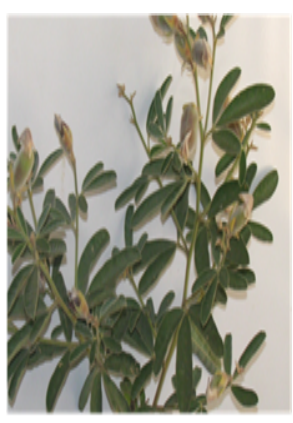

Fig. 1: Pictures of Crotalaria lachenosema Stapf. a: whole plant; b: mature

flower; c: matured fruits.
B
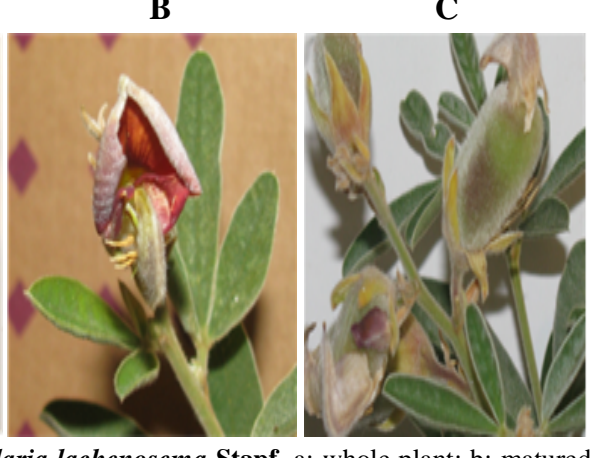


\section{Microscopic evaluation of leaf \\ Upper epidermis}

the upper epidermis shows abundant long unicellular unbranched trichomes. Trichomes bases are also seen abundant on the surface. Epidermal cells are irregular to polygonal in shape with abundant oil globules on the surface (Plate 1).

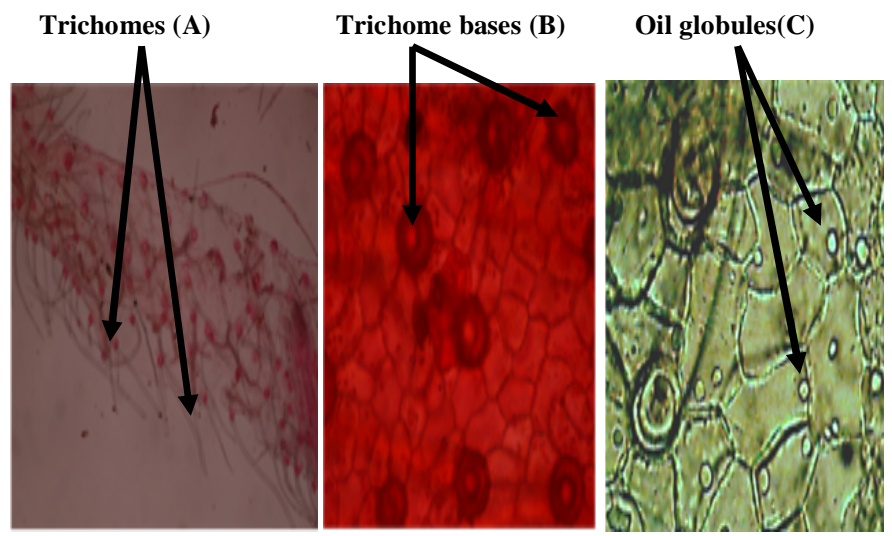

Plate. 1: Adaxial epidermal layer of Crotalaria lachenosema Stapf. a: abundant trichomes on the surface; b: polygonal to irregular cell shape and abundant trichome bases; c: abundant oil globules (arrowed).

\section{Lower epidermis}

The lower epidermal surface also shows abundant long unicellular unbranched trichomes and also abundant trichome bases. Epidermal cells are irregular to polygonal in shape. Anisocytic stomata type abundant while few anomocytic stomata type was observed. Epidermal cells were shortly and randomly striated (Plate 2).
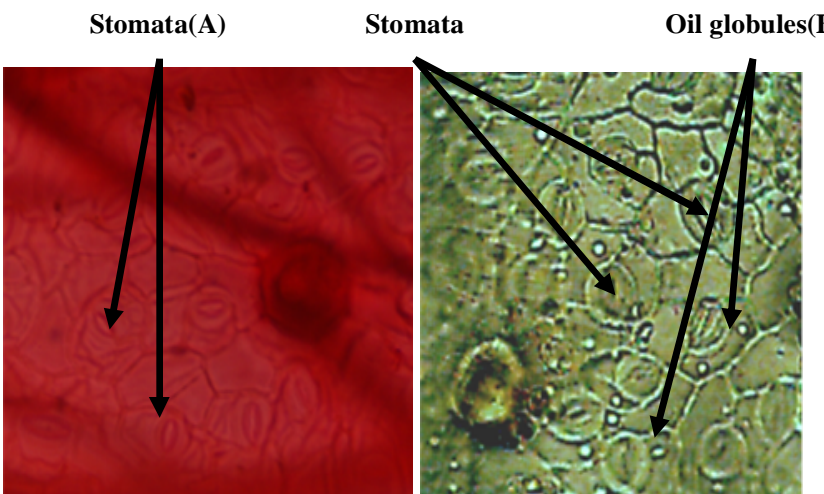

Plate. 2: Abaxial (lower) epidermal surface of Crotalaria lachenosema Stapf a: irregular cell shape and abundant stomata; b: abundant anisocytic and anomocytic stomata types, abundant oil globules.

\section{Transverse section of leaf}

Transverse section shows isobilateral leaf type with one layer of palisade cells on one surface and two layers of palisade cell on the other surface (Plate $3 b \& c$ ). Thick Midrib protruding abaxially (lower surface) while a slight groove is observed adaxially (Upper surface) (Plate 3a). Trichomes abundant on both layers of the sections (Plate 3a). Abundant oil globules are seen on the palisade, mesophyll and epidermal cells. Spiral xylem vessels also observed.

\section{Physicochemical analyses}

The physicochemical parameters are presented in Table 1.

Table. 1: Physicochemical parameters of the leaves of Crotolaria lachnosema Stapf.

\begin{tabular}{ll}
\hline Test & Results \% \\
\hline Moisture content & 13.93 \\
Alcohol extractive value & 2.16 \\
Water extractive value & 16.73 \\
Total ash value & 6.40 \\
\hline
\end{tabular}

\section{Phytochemical analyses}

The preliminary phytochemical screening revealed the presence of saponins, terpenes, sterols, flavonoids, resins and balsams while tannins, cardiac glycoside, alkaloids, phlobatannins and glycosides were absent (Table 2).

Table. 2 : Phytochemical screening of the powdered leaf of Crotolaria lachnosema Stapf.

\begin{tabular}{ll}
\hline TEST & INFERENCE \\
\hline Tannins & - \\
Saponins & + \\
Cardiac glycosides & - \\
Terpenes & + \\
Sterols & + \\
Flavonoids & + \\
Resins & + \\
Balsams & + \\
Alkaloids & - \\
Phlobannins & - \\
Glycosides & - \\
\hline Key: = positive &
\end{tabular}

\section{Thin layer chromatography}

The $R \mathrm{f}$ values of spots detected on TLC analysis of the three extracts; hexane, ethylacetate and methanol developed in the solvent system of Hex: EtOAc (9:1) is presented in Table 3,

while the $R \mathrm{f}$ values of the spots of the extracts developed in the solvent system of Hex: EtOAc: Meth $(7: 2: 1)$ is presented in Table 4

Table. 3: Retension factors $(R \mathrm{f})$ of components of organic extracts of the leaves of Crotalaria lachnosema in solvent system Hex- EtOAc (9-1).

\begin{tabular}{llllll}
\hline $\begin{array}{c}\text { Hexane } \\
\text { extract } \\
(\mathbf{c m})\end{array}$ & Colour & $\begin{array}{c}\text { Ethlyacetate } \\
\text { extract }(\mathbf{c m})\end{array}$ & Colour & $\begin{array}{c}\text { Methanol } \\
\text { extract(cm) }\end{array}$ & Colour \\
\hline 0.65 & Brown & 0.64 & Purple & 0.40 & Brown \\
0.40 & Purple & 0.40 & Purple & & \\
0.26 & Purple & 0.27 & Purple & & \\
0.25 & purple & & & & \\
\hline
\end{tabular}

Table. 4: Retension factors $(R \mathrm{f})$ of components of organic extracts of the leaves of Crotalaria lachnosema in solvent system Hex- EtOAc: Meth (7-2-1).

\begin{tabular}{llllll}
\hline $\begin{array}{c}\text { Hexane } \\
\text { extract } \\
(\mathbf{c m})\end{array}$ & Colour & $\begin{array}{c}\text { Ethylacetate } \\
\text { extract }(\mathbf{c m})\end{array}$ & Colour & $\begin{array}{c}\text { Methanol } \\
\text { extract } \\
(\mathbf{c m})\end{array}$ & Colour \\
\hline 0.89 & Brown & 0.46 & Brown & 0.69 & Brown \\
0.68 & Purple & & & 0.44 & Brown \\
0.64 & Purple & & & & \\
\hline
\end{tabular}




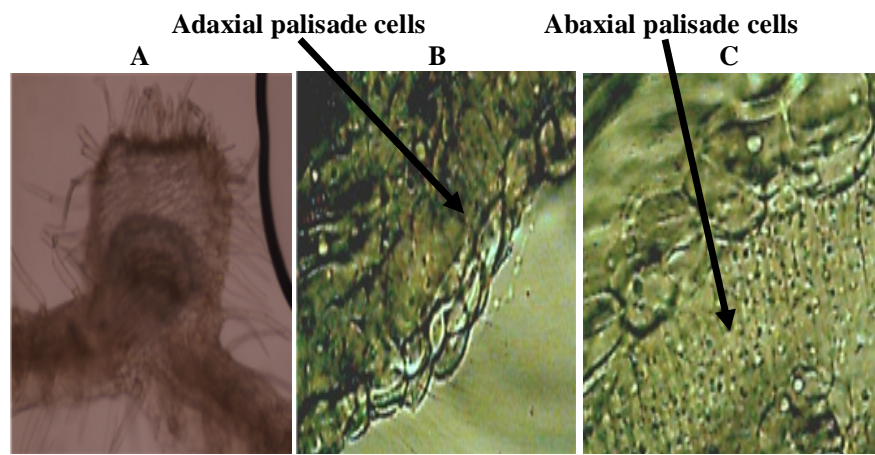

Plate. 3: Transverse sections of leaves of Crotalaria lachenosema Stapf. a: midrib projecting abaxially; b: one layer of palisade cells on adaxial surface; c: two layers of palisade cells on abaxial surface

\section{DISCUSSION AND CONCLUSION}

From the study, important diagnostic characters that might be useful in determining authenticity and identifying adulteration of the crude drug are observed. These are found in the abundant long unicellular unbranched trichomes on both adaxial and abaxial surfaces of leaves, characteristic trichome bases and striated cells at the abaxial surfaces of the leaves. Abundant oil globules seen on the mesophyll cells and epidermal cells on transverse section of leaves are also diagnostic and can be used to determined authenticity of the plant.

The moisture content of $13.93 \%$, which is within the recommended range of $8-14 \%$ for vegetable drug was an indication that the plant can be stored for a long period of time with less probability of microbial attack. The water extractive value of $16.73 \%$ showed that water permeates the cells of the leaves and thus, a better extractant compared to alcohol with extractive value of $2.16 \%$. Total ash of $6.40 \%$ was low implying that the crude plant has low inorganic components. The aim of ashing was to remove all traces of organic matter (Setia and Goyal, 2010). The total ash value can be used to detect foreign organic matter and adulteration with sand and earth, therefore, reflecting the kind of care that must be taken in preparing the plant for drug.

The presence of resins and balsams might support the ethno-use of the plant as emollient and demulcent as well as for treatment of sore throat, rheumatism, wounds and burns, since some balsams and resins has antiseptic properties (Evans, 2002). Alkaloids which are reported for some Crotolaria spp. was found absent in this species. This may be attributed to the false positive/negative results usually observed with preliminary phytoscreening of plants. It may also be that very sensitive and selective methods may be needed for their detection. The TLC profile of the organic extracts of the leaves of C. lachnosema gives a preliminary view of the secondary metabolites present. A number of spots were observed with the organic extracts with the hexane extract having the highest number of components.
Good resolution of components was achieved with the two solvent systems used. Colouration of the spots may also be vital in compound isolation and identification as compound classes such as terpenes and steroids are known to exhibit distinct colorations.

The pharmacognostic evaluation which comprises of macromorphology and microscopic characters, the estimation of physicochemical parameters and the phytochemical and TLC profile are constant features of a plant which are highly essential for raw drugs or plant parts used for preparation of phytomedicine. Therefore, the result generated from this study would be useful in identification and standardization of the plant material towards quality assurance and also for preparation of a monograph on the plant. Detailed phytochemical studies of $C$. lachnosema are ongoing in our laboratory, to establish the presence or absence of this class of compounds.

\section{ACKNOWLEDGEMENTS}

The authors wish to acknowledge the contribution of Mr. John Atogwe of the forestry Unit of National Institute for Pharmaceutical Research and Development, Idu, Abuja for cultivating the plant in our garden.

\section{REFERENCES}

African Pharmacopoeia. General Methods of Analysis. Lagos :(OAU/STRC) (1986) 143.

Arzt J and Mount ME. Hepatotoxicity associated with pyrrolizidine alkaloid (Crotalaria spp.) ingestion in a horse on Easter Island. Vet Hum Toxicol. 1999; 41: 96 - 99.

Bras G, Brooks SE, Watler DC. Cirrhosis of Liver in Jamaica. J.Pathol. Bacteriol. 1961; 82: 503-512.

Burkill HM. The useful plants of West Tropical Africa. $2^{\text {nd }}$ ed. Vol. 3. Families J-L. Royal Botanic Gardens. Kew (1995) 314-315.

Evans, W.C. Trease and Evans Pharmacognosy, $15^{\text {th }}$ Ed. London: W.B. Sanders (2002) 183-393.

Nuhu H, Abdurahaman EM, Shok M. Ethnobotanical studies on Crotalaria species found in Zaria, Northern Nigeria. Nigerian Journal of Pharmaceutical Sciences. 2009; 8:46-53.

Setia A, Goyal N. Comparative evaluation of different samples of Cinnamon. International Journal of Ayurveda and Pharmacy. 2010; 1: $606-610$.

Sofowora A. Medicinal Plants and Traditional Medicine in Africa. $3^{\text {rd }}$ Ed. Ibadan, Nigeria: Spectrum Books Limited (2008) 199 204.

World Health Organization (W.H.O.) Report on Pyrrolizidine Alkaloids. International Programme on Chemical Safety: Environmental Health Criteria, Series; 1988. No. 80.

How to cite this article:

Jemilat A. Ibrahim, Opeoluwa Makinde and Nneka N. Ibekwe. Pharmacognostic, Physicochemical Standardization and Phytochemical Analysis of leaves of Cultivated Crotalaria lachnosema Stapf.. J App Pharm Sci. 2012; 2(9): 067-070. 